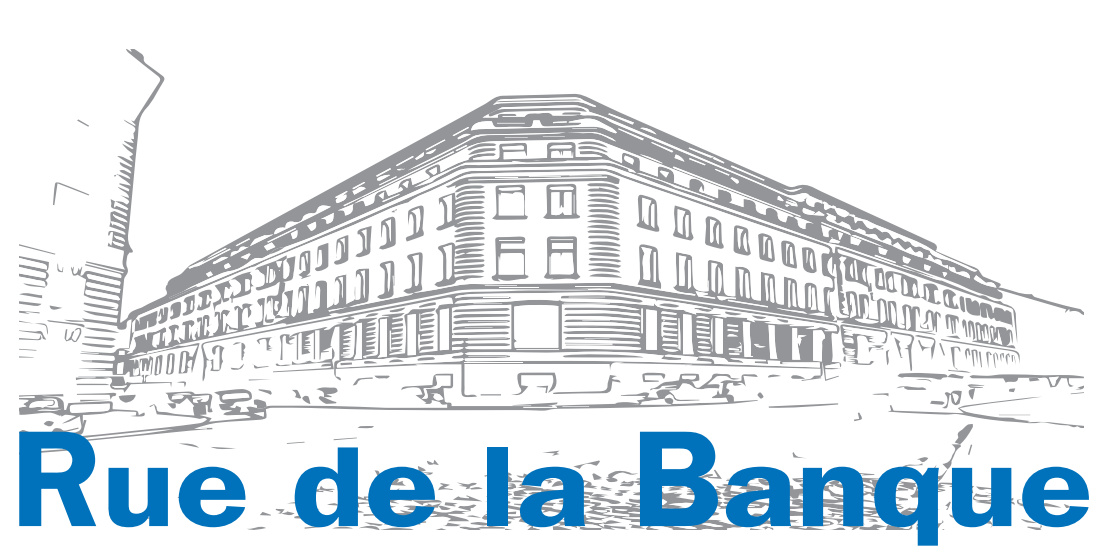

No. 67 September 2018

\title{
A DGSE model to assess the post-crisis regulation of universal banks
}

Olivier de Bandt

ACPR General Secretariat - Research and

Risk Analysis Directorate

Mohammed Chahad

Business Conditions and Macroeconomic

Forecasting Directorate

This Rue de la Banque presents the findings of research carried out at the Banque de France.

The views expressed in this post are those of

the authors and do not necessarily reflect the

position of the Banque de France. Any errors or omissions are the responsibility of the authors.

\begin{abstract}
The 2007-08 financial crisis led to a global overhaul of prudential regulatory instruments. At an international level, the new Basel III regulation increased capital requirements and also introduced two liquidity ratios, for the short and long term. This Rue de la Banque provides our latest estimates of the new regulation's long-term impact on bank lending and gross domestic product, which appears limited. It also highlights the complementarity that can arise between solvency and liquidity objectives, the degree of substitutability that can appear between the two new liquidity ratios, and the role of sovereign bonds in the new regulation.
\end{abstract}

\section{Basel III: classic prudential regulation with redefined instruments}

The new regulatory regime for banks was stabilised with the agreement on the finalisation of the Basel III reforms in December 2017. Overall, the prudential regulation of the banking sector has been radically restructured. Solvency requirements for individual banks have been enhanced. Supervision of market activities has been improved, with Basel 2.5 and Basel III and the fundamental review of the trading book. Capital requirements have been reinforced both in terms of quality and quantity: (i) the minimum Common Equity Tier 1 (CET1) ratio was raised from $2 \%$ to $4.5 \%$; (ii) the minimum Tier 1 capital ratio was increased from $4 \%$ to $6 \%$; and (iii) the minimum total capital ratio was unchanged at $8 \%$, but further constraints were imposed on capital quality. In addition, dividend payments are restricted by an additional capital conservation buffer of $2.5 \%$, comprised of CET1. Basel III was implemented in Europe on 1 January 2014 through the Capital Requirements Directive IV (CRD IV) legislative package. Furthermore, two liquidity ratios were introduced: (i) the liquidity coverage ratio (LCR) with a one-month time horizon; and (ii) the net stable funding ratio (NSFR) with a one-year time horizon. Although the definition of the LCR was approved in 2013 and transposed into European law in 2014, its implementation will only be finalised in 2019. As for the NSFR, transposition of the text published by the Basel Committee is still under discussion at the European level, based on a legislative proposal formulated by the European Commission in November 2016.

A further innovation of Basel III was the introduction of macroprudential capital buffers, which also result in stricter capital requirements at individual bank and bank group level.

\section{Instruments whose effects have been extensively discussed}

All these new regulations to reinforce bank resilience have potential macroeconomic effects, particularly on credit distribution. The literature has mainly focused on the impact of the new capital ratio for banks on the real economy. The relatively innovative nature of the Basel liquidity ratios means that the empirical literature has been unable to take inspiration from historical precedents to define a 
measurement model. ${ }^{1}$ The modelling of liquidity ratios in theoretical structural models such as DGSE models ${ }^{2}$ has generally relied on liquidity ratio proxies, such as sovereign debt as a percentage of the total balance sheet.

\section{A macroeconomic model with a well-developed banking sector and financial frictions}

In order to take proper account of the complexity of the newly introduced measures, the DGSE model we developed notably integrates two aspects, namely: (i) a wide variety of assets handled by the banking sector; and (ii) assets modelled to integrate different maturities. This latter assumption differentiates our approach from the standard DGSE models, which include one period maturity assumptions. One particularity of the model is that it applies the prudential regulation as faithfully as possible to the regulatory framework in force.

We thus developed a model that covers the euro area and builds on DSGE models that incorporate a financial sector à la Gerali et al. (2010). The banking sector balance sheet is explicitly modelled with seven types of financial instruments, including loans to large firms (LF), loans to small and medium-sized enterprises (SMEs), sovereign bonds and interest-bearing household deposits. Each instrument has its own individual interest rate and maturity.

In the model, banks seek to avoid the risk of moral hazard whereby loans granted to companies are not repaid. To achieve this, banks impose a collateral constraint by which debt service charges (principal and interest repayments) must be covered by part of the company's physical capital value. This collateral constraint applies to debt service charges for both the current period and for future periods.

However, in the case of corporate debt securities, the banking sector is not completely insured against the risk of non-repayment. It is assumed that these debt securities are issued uniquely by large firms that are subject to idiosyncratic shocks hitting the value of their production. In the event of a significant negative shock, large firms may decide to default on these bond contracts and go into liquidation. Investors on the bond markets are aware of this risk and therefore demand a return that is higher than the sovereign bond yield incorporating a risk premium based on the probability of default.

Sovereign bonds are issued by public authorities to fund possible budget deficits and can be held by both the banking sector and by households.
Lastly, the banking sector must respect three regulatory requirements: compliance with (i) the capital ratio; (ii) the short-term liquidity coverage ratio; and (iii) the long-term net stable funding ratio. Incorporating different types of assets and their differing maturities allows us to create a model that quite closely reflects the definition of these regulatory ratios.

We analyse the impact of the new prudential regulation based on a scenario of a gradual, linear increase in the regulatory ratios over a four-year period.

\section{Limited quantitative effects}

The estimated long-term effects of a one percentage point (pp) increase in the capital ratio fall within the range of measurements found in the literature (see Table 1).

An increase in the regulatory capital ratio results in a rise in banks' funding costs that lead to higher bank lending rates. This in turn contributes to a reduction in aggregate demand and more particularly in firms' investment expenditure, and thus influences GDP.

The impact of the new liquidity regulation is initially limited to the effect of a 25 pp increase in LCR on the euro area

T1 The long-term impact of a 1 percentage point increase in the capital ratio

(interest rates expressed in basis points; other variables expressed as \%)

\begin{tabular}{|c|c|c|c|}
\hline \multicolumn{4}{|c|}{ Impact in deviations from steady state } \\
\hline Paper & GDP & Bank loans & $\begin{array}{c}\text { Bank lending } \\
\text { rate }\end{array}$ \\
\hline $\begin{array}{l}\text { Bandt (de) and Chahad } \\
\text { (2016) - Euro area } \\
\text { Angelini and Gerali }\end{array}$ & -0.31 & $\begin{array}{l}-1.75 \text { (SMEs) } \\
-1.98 \text { (LFs) }\end{array}$ & $\begin{array}{l}+5.8 \text { (SMEs) } \\
+2.6 \text { (LFs) }\end{array}$ \\
\hline (2012) - Euro area & -0.36 & -1.96 & +0.31 \\
\hline $\begin{array}{l}\text { Sutorova and Teply } \\
\text { (2013) - EU }\end{array}$ & - & -0.03 & +18.8 \\
\hline $\begin{array}{l}\text { MAG }(2010)- \\
17 \text { OECD countries }\end{array}$ & -0.09 & - & +12.2 \\
\hline
\end{tabular}

Source: Bandt (de) and Chahad (2016).

Note: SMES - small and medium-sized enterprises; LFs - large firms.

1 Two exceptions are Bonner (2016) and Banerjee and Mio (2015), who were able to base their work on liquidity requirements introduced in the Netherlands in 2003 and the United Kingdom in 2010, respectively. It should be noted that France also had a liquidity ratio in place that was similar in certain aspects to the LCR. It was introduced in 1988 and its aim was to ensure that forecasted receipts exceeded disbursements over a one-month time horizon.

2 Dynamic stochastic general equilibrium model. 
T2 The long-term impact of a 25 percentage point increase in the LCR

(interest rates expressed in basis points; other variables expressed as \%)

\begin{tabular}{llll}
\hline \multicolumn{4}{c}{ Impact in deviations from steady state } \\
\multicolumn{1}{c}{ Paper } & GDP & \multicolumn{1}{c}{ Bank loans } & $\begin{array}{c}\text { Bank lending } \\
\text { rate }\end{array}$ \\
& & -0.0 (SMEs) & +0.0 (SMEs) \\
$\begin{array}{l}\text { Bandt (de) and Chahad } \\
\text { (2016) - Euro area }\end{array}$ & 0.0 & $-0.0($ LFs $)$ & $+0.0($ LFs $)$ \\
$\begin{array}{l}\text { Covas and Driscoll } \\
(2014) \text { - USA }\end{array}$ & -0.3 & -3.1 & +11 \\
MAG (2010) - & & & \\
17 OECD countries & -0.0015 & - & +25 \\
\hline
\end{tabular}

Source: Bandt (de) and Chahad (2016).

Note: SMEs - small and medium-sized enterprises; LFs - large firms.

economy. Our findings indicate a short-term effect that is similar to other models, but that cancels out in the long term to have no effect on GDP and bank lending (see Table 2).

Given the considerable weight assigned to highly rated sovereign bonds (which make up the majority of high quality liquid assets - HQLA), the banking sector could ensure compliance with the new liquidity ratio by substantially increasing its demand for sovereign bonds alone. All other things being equal, this could be achieved by encouraging households to increase their deposits at the expense of lower sovereign debts holding.

As it is assumed that the banking sector does not face any long term cost by purchasing new sovereign bonds, the LCR is therefore expected to have no long term effect. Nevertheless, in the short term the implementation of the LCR encounters constraints that lead to a transitory negative cost to the GDP dynamic; this cost is mainly observed through a reduction in household consumption spending.

\section{Weak correlations between the effects of the solvency ratio and the liquidity ratio}

Chart 1 below shows that the cumulative impact of implementing the two ratios is close to the sum of the impacts of each regulatory ratio implemented separately. This finding can be explained by the banking sector turning to two perfectly complementary strategies to achieve each of the two objectives: on the one hand, reducing banks' balance sheets and leverage for the capital ratio; and on the other, a substantial increase in sovereign debt holdings - as observed in the euro area data - and ultimately, an increase in the balance sheet for the LCR.

\section{A high degree of substitutability between the two liquidity ratios}

In contrast to the complementarity between the effects of the capital ratio and the LCR, the impacts of the two new liquidity ratios (LCR and NSFR) should show a high degree of consistency (see Chart 2 below). In other words, the efforts made by the banking sector to meet its objective in terms of the short-term liquidity coverage ratio (LCR) should also help it to meet its objective with regard to the long term stable funding ratio (NSFR).

The substitutability of the effects of the liquidity ratios is due to banks using the same instruments to achieve their objectives. Indeed, the definition of the two ratios gives considerable (positive) weight to the calibration of sovereign bonds. Consequently, the banking sector will be able to achieve a significant part of both these objectives by solely acquiring highly rated sovereign bonds (HQLA).

\section{Conclusion}

The use of structural models with a detailed banking sector is a valuable tool for measuring the effects of the new banking regulation on banks' financial activity on the one hand and the real economy on the other.

Nevertheless, it is important to specify that this study focuses mainly on the costs of the banking regulation from the perspective of its short-term impact on the business cycle. It therefore omits the medium to longterm benefits associated with the regulation, particularly greater financial sector stability and a strengthening of financial intermediaries' balance sheet structure. 


\section{Rue de la Banque}

No. 67 - September 2018

C1 Effect of the simultaneous implementation of the two prudential ratios: the capital ratio and the LCR

(interest rates shown as deviations from steady state and expressed in basis points; other variables expressed as \% deviations from steady state)

a) GDP

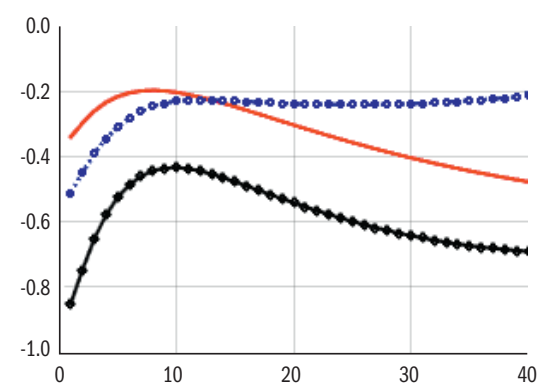

d) Private consumption

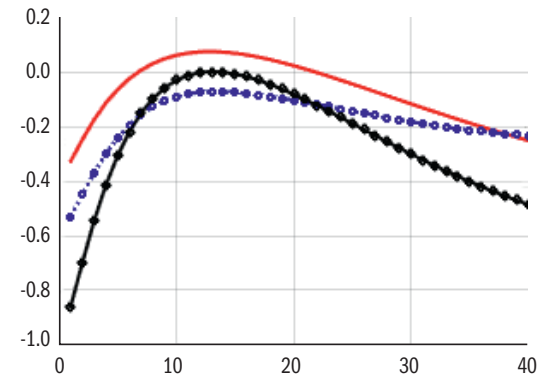

g) Households' deposits

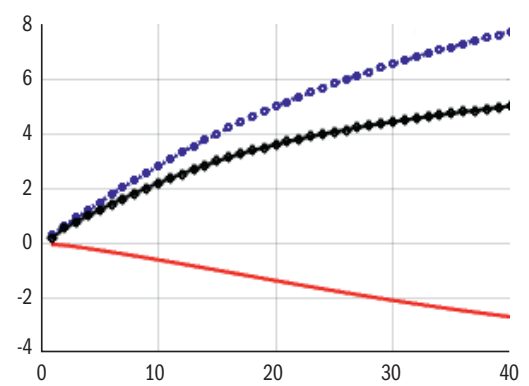

b) Inflation

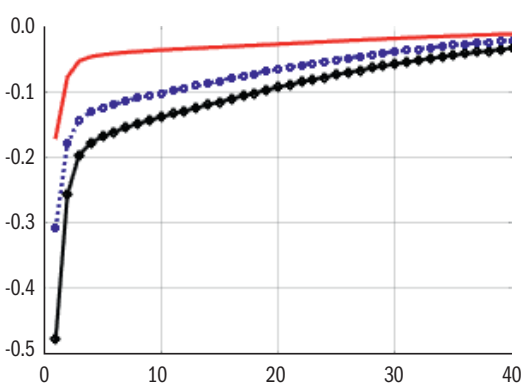

e) Private investment

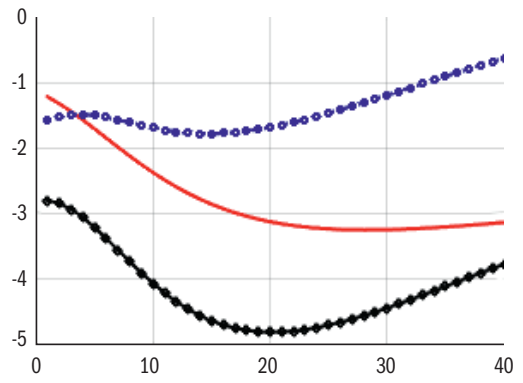

h) Sovereign bonds held by banks

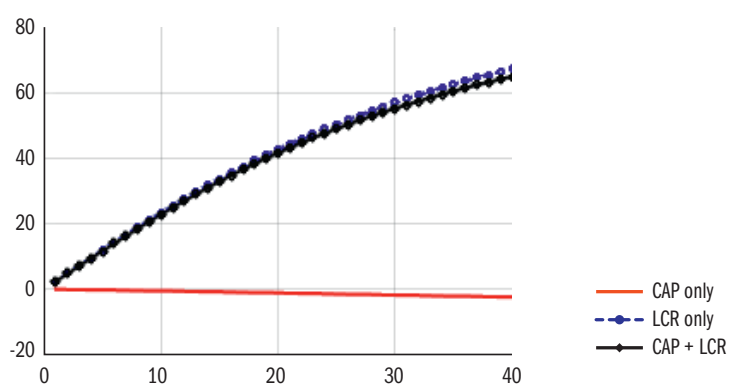

Source: Bandt (de) and Chahad (2016)

Note: Each chart measures the variable's response for different quarters (from 1 to 40). For example, in the case of GDP, -0.5 in period 1 means that during the first quarter, GDP is $0.5 \%$ below its steady state level or trend level. 


\section{Rue de la Banque}

No. 67 - September 2018

C2 Effect of the simultaneous implementation of the two liquidity ratios: the LCR and the NSFR

(interest rates shown as deviations from steady state and expressed in basis points; other variables expressed as \% deviations from steady state)

a) GDP

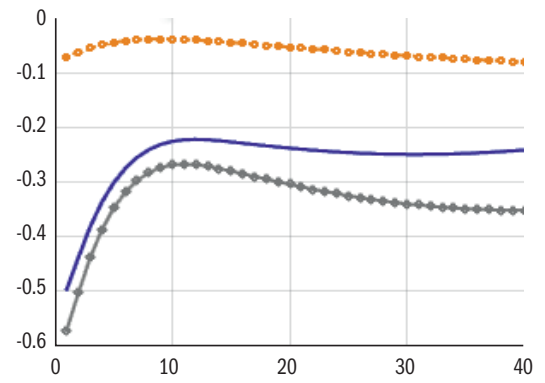

d) Private consumption

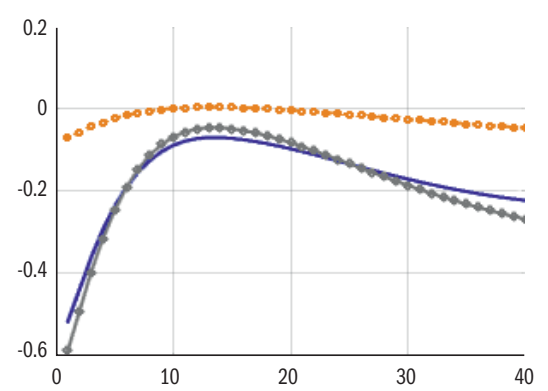

g) Households' deposits

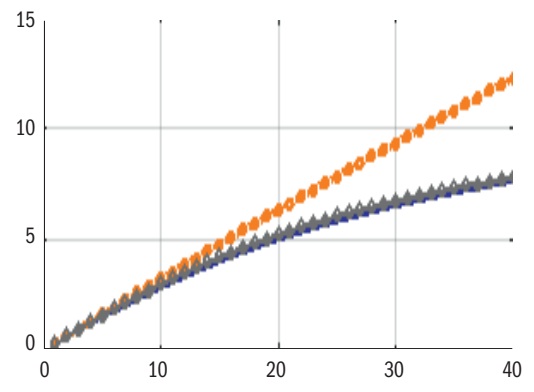

b) Inflation

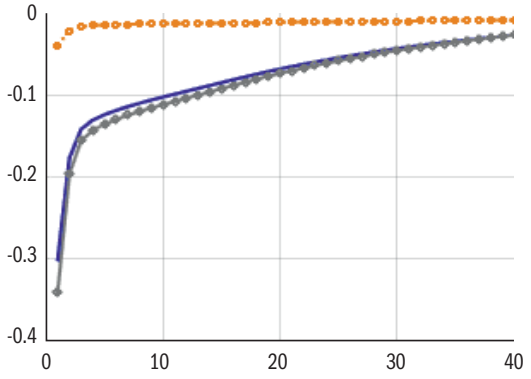

e) Private investment

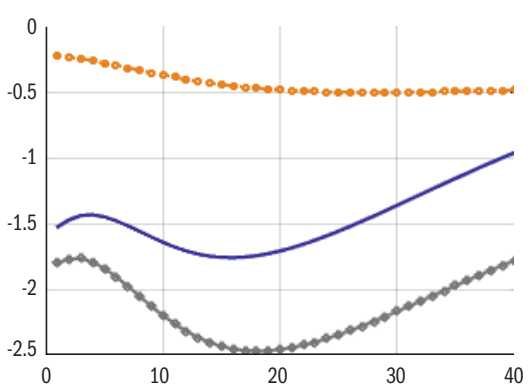

h) Sovereign bonds held by banks

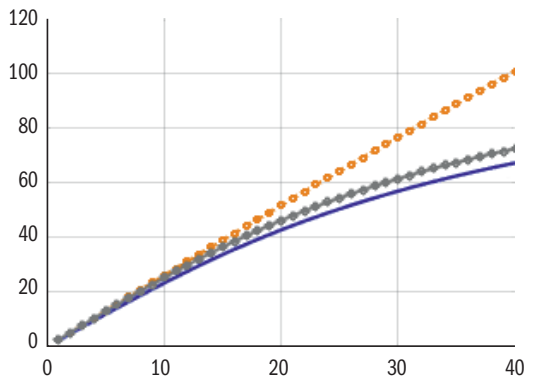

c) Short term interest rate

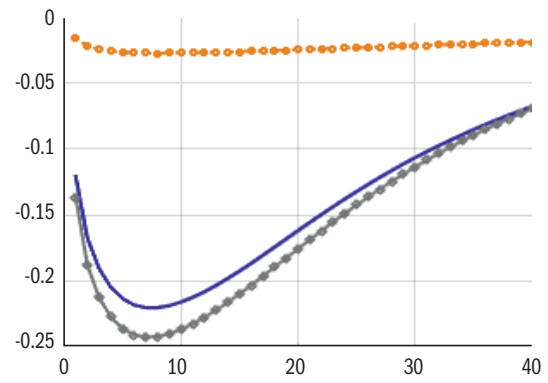

f) Banking leverage

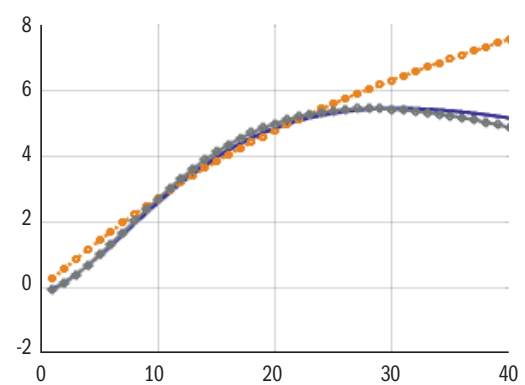

Source: Bandt (de) and Chahad (2016) 


\section{Rue de la Banque}

No. 67 September 2018

\section{References}

Angelini (P.), Clerc (L.), Curdia (V.), Gambacorta (L.), Gerali (A.), Locarno (A.), Motto (R.), Roeger (W.), Van den Heuvel (S.) and Vlcek (J.) (2011)

"Basel III: long term impact on economic performance and fluctuations", Technical Report, Bank for International Settlements, No. 338, February.

Angelini (P.) and Gerali (A.) (2012)

“Banks' reactions to Basel III”, Working Papers, No. 876, Banca d'Italia, July.

Bandt (de) (0.) and Chahad (M.) (2016)

"A DGSE model to assess the post crisis regulation of universal banks", Working Paper, No. 602, Banque de France, September.

Banerjee (R. N.) and Mio (H.) (2015)

"The impact of liquidity regulation on banks", Staff Working Paper, No. 536, Bank of England, July.

Bonner (C.) (2016)

"Preferential regulatory treatment and banks' demand for government bonds", Journal of Money, Credit and Banking, Vol. 48, No. 6, pp. 1195-1221, September.
Covas (F.) and Driscoll (J.) (2014)

"Bank liquidity and capital regulation in general equilibrium", Finance and Economics Discussion Series, No. 2014-85, US Federal Reserve, September.

Gerali (A.), Neri (S.), Sessa (L.) and

Signoretti (F.M.) (2010)

"Credit and banking in a DSGE model of the euro area", Journal of Money, Credit and Banking, Vol. 42, No. 1, pp. 107-141, September.

Macroeconomic Assessment Group - MAG (2010) An assessment of the long-term economic impact of stronger capital an liquidity requirements, Bank for International Settlements, August.

\section{Sutorova (B.) and Teply (P.) (2013)}

"The impact of Basel III on lending rates of EU banks", Czech Journal of Economics and Finance, Vol. 63, No. 3.
Published by

Managing Editor

Olivier Garnier

Editor-in-Chief

Françoise Drumetz
Banque de France
Production

Press and Communication Department

September 2018

www.banque-france.fr

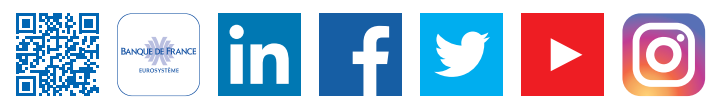

